\title{
The Philosophy of International Democracy: Essence and Ways of the Approval and Extensions \\ Dzhamal Z Mutagirov*
}

Department of Philosophic Sciences, International Political Processes of the St. Petersburg State University, Russia

"Corresponding author: Dr. Dzhamal Z. Mutagirov, Department of Philosophic Sciences, Professor of International Political Processes of the St. Petersburg State University, Russia, Tel: +7 812 328-94-55; E-mail: dezamy@mail.ru

Rec date: April 19, 2017; Acc date: July 22, 2017; Pub date: July 31, 2017

Copyright: () 2017 Mutagirov DZ. This is an open-access article distributed under the terms of the Creative Commons Attribution License, which permits unrestricted use, distribution, and reproduction in any medium, provided the original author and source are credited.

\begin{abstract}
Human rights, democracy and the rule of law, which are the goals of many national societies, require nowadays their expansion so they became the qualifiers in solving of the international problems as well. We are talking about the same phenomenon, but manifesting at various levels of the people's lives and, as a result, of the different actors' activity. Criteria for international democracy require their further systematization. The article draws attention to the paradox, when some leaders of the democratic countries, strictly observing the standards of democracy in their own countries, are opponents of the equal rights of the people and principles of international democracy. The article traces the evolution of the trends of international democracy on examples of the United Nations and European Union.
\end{abstract}

Keywords: International democracy; Principles of democracy; International law National equality; Non-interference; Justice; Selfdetermination; The will of the people; Unions of the people; The United Nations; The European Union

\section{Introduction}

In a broad sense of the word, democracy means the optimal form of relationship between free and equal people in all spheres of life and at all levels of human communities [1-4]. Actors of democracy within countries are members of their societies and citizens of the states, and those of international democracy-members of the universal civil society, entire people, societies, states and international institutions.

Accordingly, the principal agents of international relations are the people, societies and states, their unions and institutions. Individuals act here first and foremost as forming of the national institutions and their guards, performers of their laws, adherents of their customs, traditions, mentality and as representatives of distinct cultures. Just as a sole state aspires by its laws to contribute to the achievement of personal benefits, Grotius believed, so all states have some laws made together and consisting with common interests all of them together. It is the law of nations or international law [5].

\section{Literature Review}

In relations between nations democracy is no less important than in the relationship between members of the societies and citizens of the states. Just as the light, heat and humidity favour flora, so international democracy strengthens stability and mutually beneficial cooperation of all national groups of humankind, encourages a rapid and comprehensive progress of the universe. And this is possible only under conditions of freedom, equity and equality of all people and mutually friendly relations between them. If a well-being of a society depends from creative activity of all its members, the well-being of humankind depends from such of all its national groups. The advanced representatives of humankind's all generations understood that well. At the same time, they were aware of the objective difficulties in achieving peace, harmony and cooperation. The main of those are as the spirit of competition, characteristic to all living things on the Earth, so the humankind's overall level of development.

Most of the conflicts and unreasonable acts in the world were happening not only because people's ill will, but because the clear majority of them believed that such is a natural expression of human behaviour. That is why the theorists of democracy believed that an education of all population of the Earth was the best way to triumph of reason and justice. "Do enlighten the people widely, and tyranny and oppressions of body and mind will vanish like evil spirits at the dawn of the day", Jefferson advised [6].

After the first contacts of Europeans with unknown until the XVI century people in the New World with a different skin colour and stray slightly different lifestyles, the ruling circles of Spain seriously discussed on whether to consider them to be the people, do they have souls, and how they should be treated with? There were sharp discussions about this in the Salamanca University. Asserting that the indigenous inhabitants of the new world are not independent in their actions and do not belong to them, the theologians Juan Sepulveda, Juan De Kevado, etc. offered to turn them into slaves. Humanist and educator Bartolome De Las Casas strongly objected to them, defending the idea of identities of the civilization development of all people. All of them possess with a reason and will, are formed in the image and likeness of God; they all have five external and four internal feelings. All of them possess a natural ability to understand what is good and what is bad. Therefore, humankind is unique, and all people are like each other; no one is born already enlightened, Casas believed [7].

During these discussions the idea of the right of people to selfdetermination, being the basis of international democracy, has been formulated. In a lecture "On temperance", read and published in 1537, Vitoria spoke about the rights of Indians to self-determination and to control over natural resources in areas of their habitation [8]. Casas defended the Indians' rights in the treatise "On the Royal power or right to self-determination" [9]. He formulated in it three 'dogmas' of 
democracy, namely: 1) all power emanates from the people. 2) power is delegated to the rulers so that they would serve the people; 3 ) all important action of a government requires consultation with the people and their approval. "No state, king or emperor could alienate territory or change their political system without the consent of their people", he wrote. Refuting the thesis of the Spaniards right to get gold, pearls and other values in areas inhabited by Indians, Casas asked: "is it possible that our most serene King Philip and the Kingdom of Castile allowed the French King or the French penetrate without authorization in the Kingdom far to the silver mines of Guadalcanal or elsewhere, to take out the silver, gold and other precious stones?" [10].

De Las Casas' doctrine of the people' self-determination has had a significant impact on the political thought of the modernity. During formation of the national states in Europe the understanding that every nation has the right to establish their own state has formed. Most fundamentally the ideas of equality and equal rights of the people were substantiated by Jefferson. He identified the right to self-determination with the right to self-rule. "We certainly cannot deny to other nations that principle whereon our government is founded, that every nation has a right to govern itself internally under what forms it pleases, and to change these forms at its own will; and externally to transact business with other nations through whatever organ it chooses, whether that be a king, convention, assembly, committee, president, or whatever it be. The only thing essential is the will of the nation", he wrote [6]. Talking about the moral obligations of the individuals before each other in a natural state and led to a formation of the societies, Jefferson noted that such obligations relate to the societies as well. We are firmly convinced, and we act with conviction, he said in his second inaugural speech in 1805, that our relations with countries, as with people, are inseparable from our moral responsibilities, because in the long term political interest can never be separated from the moral law. He called for tolerance and understanding among people, each having their own system of moral values. "Men living in different countries, under different circumstances, different habits and regimens may have different utilities; the same act, therefore, may be useful and consequently virtuous in one country which is injurious and vicious in another differently circumstanced ", he considered [6]. Jefferson called to respect choose by other nations forms of government.

During and after the Napoleonic wars, and the reaction of the 'Holy Alliance' in Europe the rights of the people were forget, combining and separating ethnics at a discretion of the strongest states. But to suppress forever the natural aspiration of the people to independence is impossible.

Practical implementation the people's right to self-determination was one of the defining trends of the world development in the 20th century. Important moments there were the "Declaration of the rights of man and people", adopted in Russia after the October revolution of 1917, the United States President Woodrow Wilsons message to the Congress in January 1918, in which he formulated his well-known 14 points on international relations, as well as the treaties of the Conference in Paris with recognition of some new states in Europe. Their fundamental ideas were embodied in the Charter of the United Nations [11], in the UN general assembly declaration on the granting of independence to all countries and people in 1960, in both international covenants on human rights in 1966, and in the "Final act of the conference on security and cooperation in Europe" in 1975.

Jefferson's progressive evaluations were determined by the needs of the young society at the very beginning of its formation. Unfortunately, becoming the strongest nation in the world, the United States betrayed the ideas and precepts of the "founding fathers" and took the path of those, who looked at their ancestors as at unequal subjects of the colonies. However, verbally the leaders of the United States continued to maintain traditions of Jefferson. "All Nations and people are free to choose the most suitable, from their point of view, systems of government", President Truman said in inaugural address in January 20, 1949. The idea was repeated by his successor, General D. Eisenhower, saying that in the American system of values all nations are treated in the same way: "Recognizing that the protection of freedoms, like the freedom itself is one and indivisible, we treat all countries and people with equal respect and honours. We reject any innuendo to the account, as if any race, any nation, in any sense, or are low and odd "[12].

"Everyone is entitled to a social and international order in which the rights and freedoms set forth in this Declaration can be fully realized", the UDHR proclaimed in 1948 in its article 28. Adhering to these standards, the universal declaration on democracy, adopted by the inter-parliamentary union in 1997, calls all states to consider democracy as an international principle that should guide their relations with each other and with international organizations. According to the declaration, the international democracy means not only equal relations among all people and nations, but also their equal voice, regardless of their size and capabilities. Democracy must be permeated with the rights and obligations of the states as important actors of the universal community. The principles of democracy should guide in the international regulation of global issues and the common heritage of humankind, the problems of habitat. International democracy also means that the behaviour of all states must be correspond with democratically established rules of international law (Universal, Preamble), that is, the rule of law should be carried out not only within states, but also the universe. If the purpose of the national law is orientation the society's members and citizens for good and keep them from evil, international law is a set of rules of humankind's conduct [13], which should be equally focused on good and keeping from harm.

Universal democracy presupposes participation of all the people in elaboration of international law, refrain from destructive behaviour relations between them, solidarity with all forces in the world, who stand on guard of the human rights, democracy and rule of law. All democratic states must exert efforts for the approval of such international legal order, which would exclude any possibility of violations of fundamental human and people' rights, as well as deviations from the norms of international law.

The principles of universal democracy were re-established and clarified in many international agreements. But, as the saying goes, any declaration to implement the declared is much far from what was done. For the states for millennia used to watch at each other as rivals and enemies, it is not easy to get rid of deep and well-established standards of relationships, attitudes and habits.

The conditions in the world and the possibilities of the people are completely different now days than in the past. The level of their education and culture significantly has increased. The world's largest countries, which leaders conduct remains to be the main source of ongoing conflicts and rivalry, have everything-extensive areas with abundant natural resources and educated population that can create wonders in their countries. But competing between themselves, declaring the habitats of other sovereign people as zones of own strategic interests, they perform, whether they like it or not, the role of antimatter-destroyers of the people' cooperation at the universal level. 
As the American senator fulbright correctly stated, the leading powers of the world continue to be in "ecstasy of force and confused power with virtue, as well as the burden of responsibility with the mission of universal nature" (Ibid.).

To avoid that, no state should claim to be the supreme judge in the world, with the right to determine what is true and what is false, what is 'a protection of democracy' and what is an interference in the internal affairs of other nations and societies with imposing their will on them. The claims to the role of the mythical Procrustes, adjusted everybody to his own standards, are wildness in our days.

Processes of institutionalization of international life, establishment of the international organizations and associations traditionally take place with participation the state's and civil society's representatives. The processes are relatively democratic, if the representatives of the governments and civil societies are guided by norms of the constitutions of their countries and the national systems of their values. Although all established international institutions are endowed with certain authorities, and some of them are themselves a kind of supranational governments, as the United Nations and European Union, for example, with their ever-expanding and complex systems of institutions, here it is advisable direct participation of the sovereignthe people. Besides it is important, whether people participate in these processes as the officials of the state, which is only one among the multiple institutions of civil society, or in a status of the members of the society. In the first case, the official would be concerned most about the interests of the state and its role in the established institution. In the second case people will think mainly of use of the institution for his country and compatriots, and will try to minimize the possible adverse effects the institution's activities to a minimum. It would be useful to remember the discourse between Hobbes and Pufendorf about the rights, people delegate to the state, and of changes in the statuses of the citizen and the ruler. Hobbes believed that while forming the state people delegate to it all their rights and freedoms. Pufendorf criticized Hobbes for it, justly saying that people always act for own good, and therefore pass to the state only part of their rights, reserving all fundamental rights, including the right to control over the activities of the state and its reform with them. Nations being members of the supranational institutions, also delegate them only a part of their rights, reserving the most fundamental ones with them.

That can be seen visibly by examples of the United States, Soviet Union, European and African Unions, illustrating both the sequence and the metamorphosis of democracy at each new stage in the unification process. Formation of any alliance of nations on the principles of democracy is a long and arduous process; it begins with the awareness of a group of countries about their nearness interests, as well as the benefits of cooperation between them.

\section{Discussion}

After the second world war, the democracy of international relations has reinforced contrary to the heightened up cold war. With all its imperfections, all natural and artificial contradictions between states and sophisticated forms of the cold war, the maintenance of which demanded astronomical sums of money, the world order for four decades after the second world war proved to be the best, the most democratic and most favourable to the progress of humankind. Democratic principles of relations between people and nations, even accounted by the language of Aesop (the principle of sovereign equality of all member-states of the United Nations and at the same time a factual 'more equal' status of the permanent members of the UN security council, the general obligation not to interfere into internal affairs of each other and, at the same time, an international protection of the human and people's rights) were declared in the United Nations' charter. Due to collective efforts of the nations, the role of secret diplomacy has restricted considerably. The world has become more open, and humankind more informed about what was happening in it. The annual sessions of the general assembly, gathering together leaders of almost all the nations of the world, gave each of them an opportunity to appeal to the international community with their problems and concerns, and the inhabitants of the planet-to know, what primarily concerns humanity. The aspirations of the people to independence and international recognition of the right assisted to origin of more than 100 new independent states, which immediately became active participants of the world politics, and to the voice which the 'more equal' countries had to listen. As it doesn't sound weird, the division of the world into different systems and a rivalry between them has contributed significantly to this. Each of these systems has sought to attract the young and developing nations to its side, not only promising, but providing them with economic and other assistance and by supporting their status as non-aligned countries. The UN member-states had agreed on standards and rules of conduct in the seas, oceans and outer space, and declared the space, the deep seabed and its resources common heritage of humankind.

The United Nations charter proclaimed mission «to achieve international co-operation in solving international problems of an economic, social, cultural, or humanitarian character, and in promoting and encouraging respect for human rights and for fundamental freedoms for all without distinction as to race, sex, language, or religion". Of paramount importance are the universal declaration of human rights, the 'Covenant on economic, social and cultural rights' and the 'Covenant on Civil and political rights'. The states-signatories undertook to create all necessary conditions for the realization of the declared rights and freedoms. Developing the universal declaration of human rights and the international covenants on human rights, the UN, UNESCO, the council of Europe, the continental and regional institutions in Asia, Africa and Latin America have adopted hundreds of declarations and conventions on the rights and freedoms of various groups and layers of population. International atmosphere was favourable for scientific and technical, information, cultural and other revolutions, and contributed to an unprecedented so far acceleration of the growth of the world production. As at the XVII congress of the socialist international has noted in 1986, $80 \%$ of the total economic growth in the world in the 20th century was achieved in the period from 1950 to 1985 , when the economic growth in the world were the highest in the history of humankind-approximately $5 \%$ per year [14].

The world had got certain balance of power, which did not give either party a noticeable superiority and the key actors sought to preserve this balance. Almost all conflicts in 1960 to 1980's, except for the Vietnam War, were aimed at preventing a reversal of the balance of power in the world.

The long cold war between two social systems little by little changed this ratio, led to the restoration of the capitalist order in several countries and the beginning of a new phase in international relations. With the collapse of the Soviet Union and disappearance of one of the parties of antagonism must disappear the hostile antagonism as well, the cold war, and will weaken the contradictions between the leading nations of the world; the world order should become more harmonious 
and without conflicts, which, naturally, will lead to further acceleration the social progress' pace. President of the United States Bush the senior said in his message to Congress in September 11, 1990 that it will be an era, freer from fear, stronger in the pursuit of justice and more confident in achieving peace, the era, when the people of the world will achieve prosperity. It will be a world, where the rule of law replaces the rule of the jungle, a world in which the people recognize assumed responsibility for freedom and justice, a world where the strong will to respect the rights of the weak, the president of the United States predicted. Even search for formulas of a new world order started.

There were hasty and exaggerated assessments of the new situation in the world also in essays of some American authors (Fukuyama, Huntington). When many expectations not only failed, but new threats emerged, and the 'new' once again turned out to be worse than the old, they begun to argue about a 'Clash of civilizations', although many conflicts took place within, rather than between them. It would be more accurate to define a new stage in the development of international relations as "The stage of the old rivals fights with new armour and under new slogans".

The United States, be considered as the winner in the cold war, felt that they have the right to define the fate of not only defeated countries, but the world, i.e., to become its ruler. At last, it seemed, that the age-old dream of the United States is fulfilling. Woodrow Wilson, developing the spirit of the 'Manifest of Destiny', guiding by which the United States had extended from the Atlantic to the Pacific oceans, announced during the presidential campaign of 1912 that he believed "that God has planted in us visions of liberty...that we are chosen and prominently chosen to show the way to the nations of the world how they shall walk in the paths of liberty'. Bush Jr. in fact drove himself as Lord of the world. "We are now an empire, and when we act, we create our own reality. We are creators of history that others must simply learn", he said. The prime minister of the United Kingdom Blair acted in unison with Bush. In a 1997 speech Blair said: 'century upon century it has been the destiny of Britain to lead other nations. That should not be a destiny that is part of our history. It should be part of our future. We are a leader of nations or nothing. The claims of this kind and determined by them foreign policy has led to the rapid destruction of the world order and to return to one of the 19th century, but with many participants.

Dividing the world into 'friends' and 'enemies' of Washington, as at times of the ancient Rome, attributing some of the 'enemies' to 'rogue states', and the imperial aspirations of the White House, have distorted the principles of democracy in international relations. The so-called 'humanitarian' interventions, carried out primarily on the initiative of the United States after 1991 [15], began to resemble the intervention of dictatorial and tyrannical regimes in the states where the people rebelled against their rulers. Their effects in almost all cases were tragic for the 'survived' and 'democratized' countries-Somalia, Bosnia, Iraq, Libya, Afghanistan, Ukraine, etc. Some of them were performed not only without the consent of the United Nations, but contrary to its prohibition, such as in Kosovo in 1999.

Termination of economic aid to developing countries after the end of the rivalry between the contesting systems and disappearing of the need to engage them on their side, as well as economic sanctions against countries, refusing to unquestioningly obey the will of Washington, have led to a slow-down in development of almost all countries of the world. Natural consequences of it became lowering of living standards in some of them and slowing its growth in others, as well as frequent economic crises. Undue interference of developed countries in life and culture of the rest of the world has given rise to a new resistance movement, including in the form of terrorism [16] that in turn was used by the great powers as a pretext to justify a continuing increase of the military expenditures, as well as attacks on signed in 1950 to 1980 international agreements on human and people' rights.

The most intelligible and natural way of democratization of international life is an application at the global level the same principles that have contributed to the democratization of national life. If the actors of democracy in separate countries are their citizens collectively, their active majority, at the universal level this role execute all sovereign nations and their unions, also acting under the law of majority with due respect for the opinion of the minority. They all must treat each other as equal partners, having the same rights and obligations. But, unfortunately, such a conscious aspiration to promote democracy among all the people of the world did not exist in the time of creation of the United Nations.

So, each of the five permanent members of the security council has greater rights and opportunities in discussing issues of international life than the other UN member states all together, and its veto could undermine their collective will. They set the rules by which the world must live. In the end of the second world war, it was to some extent understandable. The UN was set up as a kind of 'Orchestra of the peace', in which the 'places' were defined in accordance with contribution of the states to the defeat of Germany and its allies, as well as with their role and status in the world in those specific conditions. This determined also the structure, functions and powers of the governing bodies of the United Nations. The Soviet Union, the United Kingdom, and the United States played a decisive role in the defeat of the common enemy of humankind, and rallied around them all the people fought against it or remained neutral. The UN was created as a tool to maintain and consolidate the spirit of the nations, united for a common purpose. The role of the conductor of this 'Orchestra' was assigned to the five leading countries simultaneously, each of which had its own goals. Hence the right of each of the 'big five' to absolute veto, emergency powers of a conductor and the role of the choir, reserved for the rest states.

The situation in the world and the relationship between the countries has noticeably changed almost immediately after the start of the activities of the United Nations. For decades after the war, new generations of people grew up; the political map of the world has changed beyond recognition. Germany and Japan from sources of threats to the peace, as they were when UN was formed, have turned into the states, committed to peace and democracy. A dictatorial authority, delegated to the victorious powers, is not more justified now; rather they harm the cause of peace and security on the Earth. Especially as, these countries, except China, have become in the following decades the main perpetrators of whipping up international tension. The United Nations reform in the direction of transformation into a truly global institution for peace and cooperation based on true equality of the people is, therefore, one of the most important conditions for the approval and extension of international democracy.

\section{Conclusion}

According to laws of nature and nations, the principal agents of international relations are the people and formed by them societies and states. All the people are parts of humankind with equal rights, and that is recognized in international law. Fundamental objectives of all individuals and people are survival, communication, coexistence, 
Citation: Dzhamal Z Mutagirov (2017) The Philosophy of International Democracy: Essence and Ways of the Approval and Extensions . J Socialomics 6: 213. doi:10.1472/2167-0358.1000213

Page 5 of 5

cooperation to solve human problems, creative work for obtaining the means of subsistence, while maintaining the autonomy and freedom of action, and much more. Substitution of people as the main actors in international relations by states established as societies' institutes of special competence-institutes for the protection of human rights and security-leads to a change the relationship between the principal actors of world politics and international law: Instead of cooperation of the equal people occur a rivalry of leviathans which differ in strength and appetite. There can be no equality among them, except of declaratively.

Predicting the future development of the international political processes, it can be assumed that the principal actors of the world politics then will be not the states directly, but forming by them, and based on the principles of democracy unions of the people of entire regions and continents. This will be a repeat of the transition from direct democracy to representative at the global level, with all its pros and cons. The pros will consist in reducing number of the parties to deal with the emerging international issues and in opportunities for their well-timed solving. But solutions to these problems will be defined through a multi-levels discussion-at the national, federal and global levels, reducing the possibility of haste and errors. Cons would be related to the possible alienation of the representatives of the people in the unions' authorities, as well of the representatives of unions in global bodies from electorate, as it is traditional for the parliamentarians. But one may to believe that some effective ways, firstly, to prevent such a separation, and, secondly, to the quick fix of situation, when this will happen, will be found.

\section{References}

1. Michael M (2007) Democracy's good name: The rise and risks of the world's most popular form of government. ISBN 9781586486303.
2. Jorgen $M$, Swend-Erik $S$ (2012) Democracy and democratization in comparative perspective. Routledge. pp. 1-242.

3. Mutagirov DZ (2014) Democracy as universal value. Logos, Nigeria.

4. Richard Y (2015) The puzzle of non-western democracy, ISBN 978-0-87003-430-5, England.

5. Grotius H (1998) On the law of war and peace. Batoche Books, Athens, Greece-

6. Thomas Jefferson Memorial Association (1905) The writings of Thomas Jefferson. Albert Ellery Bergh (ed), Millennium edition. 19: 7-16.

7. Martínez MM (1977) Las Casas on the conquest of America: Friede and Keen, Las Casas in history. Prague.

8. The legacy of Bartolomé de Las Casas by Benjamin Keen (1986) En el quinto centenario de Bartolomé de Las Casas. Madrid, Spain.

9. Perena L, Perez-Prendes JM, Abril V, Azcárraga J (1969) De regia potestate o derecho de auto determinacion. Madrid, Spain.

10. Fried J, Keen B (1977) Las Casas in History. Prague.

11. The UN Charter (1945) The Charter of the United Nations: Dag Hammarskjöld Library's collection of translations of the UN Charter. United Nations Conference on International Organization, San Francisco, USA.

12. Ross H, Henry K (1997) Public diplomacy: A conceptual framework.

13. Bruno L (2009) Freedom and the law. Liberty fund, Indianapolis.

14. XVIIH Congress of the Socialist International (1990) To economic security: A strategy for long-term survival: Working class and the modern world.

15. Andrew W (2006) Liberalism and war. The victors and the vanquished. Routledge, Taylor \& Francis Group, UK.

16. Mutagirov DZ (2016) Philosophy of modern terrorism. Politbook. 